\title{
Access to Work Product of Disqualified Counsel
}

An increasingly important aspect of litigation is the possibility that one party may seek the disqualification of the opposing party's counsel. Disqualification of an attorney for ethical violations may serve a number of functions: it may serve to punish misbehavior, to preserve confidences threatened by conflicting representation, or to maintain the appearance of propriety of the profession. ${ }^{1}$ After years of grappling with the problems of enforcing ethics in an adversary system, the courts have only recently begun to achieve a sensible accommodation between the competing interests in the disqualification controversy. ${ }^{2}$

Still unresolved, however, is the problem of the aftermath of disqualification: specifically, what portion of the legal work done by a disqualified attorney may be passed on by the client to substitute counsel. The solution to this problem is crucial to an equitable restoration of the adversarial balance disrupted by disqualification of one party's counsel. By denying access to work product of disqualified counsel, the court may impose on a party the onerous burden of beginning his case anew and on the system the waste of judicial resources involved in repeating the possibly prolonged process of

1 No other profession seems so collectively conscious of its public image, to so little apparent avail, as the bar. Recent literature on the subject includes G. HAZARD, ETHics IN THE Practice of Law (1978); Morgan, The Evolving Concept of Professional Responsibility, 90 Harv. L. REv. 702, 702 (1977) (noting an "increasing attack" on the Code of Professional Responsibility as "irrelevant, internally inconsistent, and conspiratorial"); Symposium, Ethical Responsibilities of Corporate Lawyers, 33 Bus. LAw. 1173 (1977). See also Joiner, Teaching Professional Responsibility, 64 A.B.A.J. 551 (1978).

2 See Note, The Second Circuit and Attorney Disqualification-Silver Chrysler Steers in a New Direction, 44 Fordham L. Rev. 130 (1975). See generally Liebman, The Changing Law of Disqualification: The Role of Presumption and Policy, 73 Nw. U.L. REv. 996 (1979). The courts have in general been receptive to challenges based on breach of professional ethics because of their responsibility for upholding the integrity of the judicial process. See, e.g., First Wis. Mortgage Trust v. First Wis. Corp., 584 F.2d 201 (7th Cir. 1978) (en banc); IBM v. Levin, 579 F.2d 271, 283 (2d Cir. 1978); Schloetter v. Railoc of Ind., Inc., 546 F.2d 706 (7th Cir. 1976); Emle Indus., Inc. v. Patentex, Inc., 478 F.2d 562, 564-65 (2d Cir. 1975). Increasingly, however, courts have expressed a troubled awareness of the use of such challenges for their harassment value alone. See Board of Educ. v. Nyquist, 590 F.2d 1241, 1246 (2d Cir. 1979); Central Milk Producers Coop. v. Sentry Food Stores, Inc., 573 F.2d 988 (8th Cir. 1978); Woods v. Covington County Bank, 537 F.2d 804, 813 (5th Cir. 1976); International Elec. Corp. v. Flanzer, 527 F.2d 1288, 1289, 1293-95 (2d Cir. 1975). Courts have also expressed the view that they should not be turned into disciplinary forums. Board of Educ. v. Nyquist, 590 F.2d 1241, 1248 (2d Cir. 1979) (Mansfield, J., concurring); W.T. Grant Co. v. Haines, 531 F.2d 671, 677 (2d Cir. 1976); Lefrak v. Arabian Am. Oil Co., 527 F.2d 1136, 1141 (2d Cir. 1975); Ceramco, Inc. v. Lee Pharmaceuticals, 510 F.2d 268 (2d Cir. 1975). 
discovery and other pretrial matters. Yet, in some cases access to disqualified counsel's work product would negate the remedial effect of disqualification. The decision whether to allow access must focus upon whether denial will promote the policy served by a particular disqualification order. This comment examines the justification for denial of access to work product in light of the policies underlying disqualification of counsel and evaluates the reasoning applied by the few courts that have faced the issue. ${ }^{3}$ The comment then analyzes the situations in which disqualification commonly occurs $^{4}$ and suggests a method for determining when access to work product should be permitted.

\section{The Problem in Context}

\section{A. The Scope of Work Product Affected by Disqualification}

The process of litigation is largely conducted through the medium of written documents. The parties submit to the court a vast array of written material: pleadings, interrogatories and answers, depositions, affidavits, motions, trial transcripts, memoranda, and briefs. Perhaps even greater in quantity are the supporting materials that the parties accumulate for their own use in preparation for trial, including primary documents, factual summaries, notes of conversations or interviews, and legal analyses of both substantive and procedural issues. When a party's counsel is disqualified, the issue of substitute counsel's access to the work product ${ }^{5}$ generated

3 First Wis. Mortgage Trust v. First Wis. Corp., 584 F.2d 201 (7th Cir. 1978) (en banc), is the first reported case involving an in-depth examinaton of the work product access question. Other cases in which the courts allowed access to the work product without extended discussion include: IBM v. Levin, 579 F.2d 271 (2d Cir. 1978); Fund of Funds, Ltd. v. Arthur Andersen \& Co., 567 F.2d 225 (2d Cir. 1977); W.T. Grant Co. v. Haines, 531 F.2d 671 (2d Cir. 1976); Ceramco, Inc. v. Lee Pharmaceuticals, 510 F.2d 268 (2d Cir. 1975); Allied Realty of St. Paul, Inc. v. Exchange Nat'l Bank, 408 F.2d 1099 (8th Cir.), cert. denied, 396 U.S. 823 (1969); E.F. Hutton \& Co. v. Brown, 305 F. Supp. 371 (S.D. Tex. 1969). The most thorough opinions to date denying access to work product are First Wis. Mortgage Trust v. First Wis. Corp., 571 F.2d 390, vacated, 584 F.2d 201 (7th Cir. 1978) (en banc), and Edilcentro Int'l, Ltd. v. Porco, No. 75-6488 (S.D.N.Y. Dec. 12, 1978).

- The focus will be on those canons most often involved in disqualification proceedings, specifically: Canon 4 ("A Lawyer Should Preserve the Confidences and Secrets of a Client"), Canon 5 ("A Lawyer Should Exercise Independent Professional Judgment on Behalf of a Client"), and Canon 9 ("A Lawyer Should Avoid Even the Appearance of Impropriety"). Breaches of the other canons may well merit discipline, but will only rarely appear in the context of disqualification. Board of Educ. v. Nyquist, 590 F.2d 1241, 1246 (2d Cir. 1979). See, e.g., W.T. Grant Co. v. Haines, 531 F.2d 671 (2d Cir. 1976) (direct contact with opposing party); Fisher Studio, Inc. v. Loews, Inc., 232 F.2d 199, 204 (2d Cir.), cert. denied, 352 U.S. 836 (1956) (solicitation).

s The term "work product" as used in this comment embraces all these possible categories of material. The term is used more broadly than in the discovery context, where the 
by the disqualified attorney may form the basis of a continuing controversy. The most important situation raising the work-product issue is that in which the attorney is disqualified because of prior representation of an opposing party in a matter substantially related to the current lawsuit. ${ }^{6}$ In such a case, the attorney is disqualified because of the danger that confidences and secrets gained during the prior representation might be used in the current lawsuit. There is also the danger that the work product of the attorney might be "tainted"- that it might contain or reflect confidential information. Different categories of work product are more or less likely to be tainted. Legal research and analysis on procedural aspects of the litigation or work product concerning substantive areas not related to the prior representation, for example, would seem to pose little danger. ${ }^{7}$ Seemingly routine legal work may, however, be found to have benefitted from the breach of confidence. Initial pleadings almost always appear unobjectionable; yet there have been cases in which the pleadings themselves were inspired by illicitly obtained information. ${ }^{8}$ In such cases, the pleadings must be struck and the files sealed.

\section{B. The Procedural Posture}

Once an attorney has been disqualified, either party may raise the issue of access to the disqualified attorney's work product. The party who successfully sought disqualification might seek a court order denying work-product access to his opponent's substitute counsel, either as a part of the motion for disqualificaton or after disqualification has been granted. ${ }^{9}$ The client of the disqualified

\footnotetext{
"work-product privilege" prevents the disclosure to the adverse party of some types of an attorney's trial preparation materials. See generally Hickman v. Taylor, 329 U.S. 495 (1947); Frd. R. Civ. P. 26(b)(3); 4 Moore's Fedraral Practice Tा 26.63-.64 (2d ed. 1976). In the disqualification context, a litigant seeks to pass the work product of his own attorney, now disqualified, to the substitute counsel. The adverse party may object to this transfer, but does not seek access for his own use. Cf. First Wis. Mortgage Trust v. First Wis. Corp., 584 F.2d 201, 211 n.5 (7th Cir. 1978) (en banc) (plaintiff offered to drop objection to transfer of work product on condition that plaintiff also be allowed access to the materials).

- See text and notes at notes 61-62 infra.

7 But see Edilcentro Int'l, Ltd. v. Porco, No. 75-6488, slip op. at 5-6 (S.D.N.Y. Dec. 12, 1978). Similarly, work performed before the cause for disqualification arose is likely to be untainted.

B.g., Doe v. A Corp., 330 F. Supp. 1352 (S.D.N.Y. 1971), aff'd per curiam sub nom. Hall v. A. Corp., 453 F.2d 1375 (2d Cir. 1972); Slater v. Rimar, 462 Pa. 138, 338 A.2d 584 (1975). But see Fund of Funds, Ltd. v. Arthur Andersen, 567 F.2d 225 (2d Cir. 1977).

- Cases in which injunctive relief was requested in addition to the disqualification include Fund of Funds, Ltd. v. Arthur Andersen, 567 F.2d 225 (2d Cir. 1977) and W.T. Grant Co. v. Haines, 531 F.2d 671 (2d Cir. 1976).
} 
attorney might raise the issue through substitute counsel, by moving for an amendment of the disqualification order $^{10}$ or by filing a motion for authorization to use the work product. ${ }^{11}$ Substitute counsel's motivation for raising the issue himself is to avoid the possibility that he might subsequently be disqualified as a result of having used tainted materials. ${ }^{12}$ In particular, where disqualification results from a claim of counsel's access to confidential information or use of information obtained in the course of prior representation, substitute counsel follows a safer course by awaiting court approval before touching the possibly tainted files.

When a client's request that substitute counsel be allowed access to the disqualified attorney's work product is denied by a federal district court, the client is not without recourse. If an order regarding access is made as a part of the disqualification decision itself, it should be appealable along with the disqualification order..$^{13}$ Whether a separate order denying work-product access is appealable is a more difficult question. The Seventh Circuit, in First Wisconsin Mortgage Trust v. First Wisconsin Corp. ${ }^{14}$ recently held an order denying access to the work product of the predecessor attorney to be appealable, despite its apparent lack of finality. ${ }^{15}$ Although the court found that the appeal from an order denying access fell within the "collateral order exception" to the finality rule, ${ }^{16}$ it is not clear

10 Such a motion would be pursuant to rules 52(b) and 59(e) of the Federal Rules of Civil Procedure. This procedure, as one court has noted, "might be the proper method to raise the issue of work product access after attorney disqualification in future cases." First Wis. Mortgage Trust v. First Wis. Corp., 571 F.2d 390, 395 (7th Cir.), vacated, 584 F.2d 201 (7th Cir. 1978) (en banc). The approach may often be impracticable, however, because such motions must be made within ten days of the disqualification order. FED. R. Crv. P. 52(b), 59(e). Some litigants might have difficulty procuring satisfactory substitute counsel so quickly.

"This procedure was used in First Wis. Mortgage Trust v. First Wis. Corp., 584 F.2d 201, 203 (7th Cir. 1978) (en banc).

12 See, e.g., P \& M Elec. Co. v. Godard, 478 S.W.2d 79 (Tex. 1972), in which substitute counsel retained to defend against disqualification of the original attorney subsequently faced a motion for disqualification based on a claim that he had been exposed to confidential information through the first attorney's work product.

${ }^{13}$ In IBM v. Levin, 579 F.2d 271 (2d Cir. 1978) and W.T. Grant Co. v. Haines, 531 F.2d 671 (2d Cir. 1976), the court of appeals ruled on the propriety of district court orders permitting access to work product in the course of appeals from the disqualification orders. The case for appellate review of an order denying access would seem even stronger, because the appeal would be filed by the same party protesting the disqualification.

14 584 F.2d 201, 203 (7th Cir. 1978) (en banc) (adopting as the opinion of the en banc court part II of the panel opinion, 571 F.2d at 392-96).

${ }^{15}$ See 28 U.S.C. $\$ 1291$ (1976) ("The courts of appeals shall have jurisdiction of appeals from all final decisions of the district courts of the United States.") (emphasis added).

16571 F.2d at 392-96. See Cohen v. Beneficial Indus. Loan Corp., 337 U.S. 541 (1949). The Seventh Circuit identified four elements of the collateral order exception: (1) the order 
that other courts will reach the same conclusion. ${ }^{17}$ Orders granting access, on the other hand, should never be appealable under the collateral order exception because the error, if serious, could be remedied upon appeal from final judgment. ${ }^{18}$

\section{The Cost of Reproducing Lost Work Product}

When an attorney is disqualified, his client incurs certain costs, whether or not the client abetted or even knew of his attorney's ethical infraction. The client is deprived of the counsel of his choice, and the legal action is delayed while substitute counsel is located and that counsel prepares for litigation. ${ }^{19}$ When the court denies substitute counsel access to the work product of his predecessor, the client may suffer a more tangible loss, for he is denied the use of legal work for which he may have paid, or might still be billed.

Although the Seventh Circuit has assumed that the client will bear the cost of denial of access to work product, ${ }^{20}$ a number of state courts have held that the loss should be borne by the disqualified attorney. The California Court of Appeals, in Goldstein v. Lees, ${ }^{21}$ admitted an attorney's ethical infraction as a defense against his subsequent suit for fees. The clients had retained the services of a law firm in connection with a proxy fight to gain control of a corpo-

must present an "important and unsettled question of law," (2) it must not be susceptible of effective review on appeal from final judgment, (3) it must be independent of the main cause of action, and (4) the danger of denying review must outweigh the inconveniences and cost of piecemeal review. 571 F.2d at 393. It is debatable whether the work-product decision involves an important and unsettled issue of law. As the First Wisconsin case itself illustrates, the factual variations make general legal principles difficult to apply. It might also be argued that the injury to the party denied access, although irreparable, is no more serious than many costly discovery orders.

17 The court noted that "once the disqualification decision has been made, the factual differences surrounding the issue of access to work product are few." 571 F.2d at 394. At least in the Seventh Circuit, the question of access might not be regarded as important and unsettled in subsequent cases.

is Cf. Comment, The Appealability of Orders Denying Motions for Disqualification of Counsel in the Federal Courts, 45 U. CHI. L. REv. 450 (1978) (arguing that orders disqualifying attorneys should be appealable, but that orders denying disqualification should not be).

" See, e.g., Government of India v. Cook Indus., Inc., 569 F.2d 737, 739 (2d Cir. 1978). See also W.T. Grant Co. v. Haines, 531 F.2d 671, 677 (2d Cir. 1976).

${ }^{20}$ First Wis. Mortgage Trust v. First Wis. Corp., 584 F.2d 201, 205, 209 (7th Cir. 1978) (en banc); accord, Edilcentro Int'l, Ltd. v. Porco, No. 75-6488, slip op. at 3 (S.D.N.Y. Dec. 30, 1977); Note, Attorney Disqualification and Access to Work Product, 63 Cornell L. REv. 1054, 1072 \& n.79 (1978). The dissent in First Wisconsin did not share the majority's tacit assumption that a denial of access would necessarily place the full economic loss on the disqualified attorney's client, 584 F.2d at 220, although Judge Castle noted that the "relative culpability" of the attorneys and their former client was not the main object of concern. Id. at $219 \mathrm{n} .13$ (dissenting opinion).

${ }^{21} 46$ Cal. App. 3d 614, 120 Cal. Rptr. 253 (1975). 
ration to which the firm had formerly been general counsel. Although only the corporation could have been injured by the ethical violation, the court nevertheless absolved the clients from liability for fees, saying that "such representation is improper and . . . a contract to provide such services is void for reasons of public policy."22 Subsequent decisions have extended the rationale of Goldstein to cases involving adverse representations in unrelated matters. ${ }^{23}$

Rather than requiring that either the client or the disqualified attorney exclusively bear the cost of disqualification, the most likely outcome is that the client and the disqualified attorney will each bear a portion of the cost. ${ }^{24}$

The incidence of the loss resulting from the denial of access to work product necessarily has a bearing on the decision whether to

22 Id. at 617,120 Cal. Rptr. at 254. The court relied on earlier state supreme court precedent. Anderson v. Eaton, 211 Cal. 113, 116, 293 P. 788, 789 (1930); Clark v. Millsap, 197 Cal. 765, 785, 242 P. 918, 926 (1926). The California Rules of Professional Conduct are more explicit than the comparable provisions of the ABA Code of Professional Responsibility. California Rule 4-101 states:

A member of the State Bar shall not accept employment adverse to a client or a former client, without the informed and written consent of the client and former client, relating to a matter in reference to which he has obtained confidential information by reason of or in the course of his employment by such client or former client.

The court in Goldstein recognized that its ruling resulted in a "windfall" to the clients, but nevertheless insisted that "[c]ourts do not sit to give effect to . . . illegal contracts." " 46 Cal. App. 3d at 624, 120 Cal. Rptr. at 258 (footnote omitted) (quoting Valentine v. Steward, 15 Cal. 387, 405 (1860)).

25 In re Hansen, 586 P.3d 413, 417 (Utah 1978) (requiring attorney to return fees already paid by client); Jeffry v. Pounds, 67 Cal. App. 3d 6, 9, 136 Cal. Rptr. 373, 375 (1977) (denying disqualified attorney unpaid fees because "acts of impropriety inconsistent with the character of the legal profession and incompatible with the faithful discharge of professional duties will prevent an attorney from recovering for his services"). In Jeffry, the court rejected the trial court's conclusion that since there was no danger of prejudice from disclosure, the attorney should be able to recover his fee. The court of appeals concluded that this unduly narrowed the scope of the rule. The court emphasized that its holding was not dependent on a finding of deliberate unethical conduct. Id.

${ }^{24}$ The allocation of the loss between client and attorney will depend on a variety of factors: any prior agreement between attorney and client, the nature of their continuing relationship, the culpability of the attorney, the client's advance knowledge of the risks involved in continuing the representation and possible acceptance of that risk as part of the price for the attorney's representation, and the portion of the client's bill paid or left unpaid at the time of disqualification.

Partners of major law firms responding informally to our inquiries emphasized the importance of the client's full knowledge of the possible disqualification to the allocation of the financial loss. Where the client is fully informed, he is thought to have assumed the risk of disqualification.

The importance of the status of payments on the client's bill is procedural: if the client has already paid, he must sue in order to recover his payments; if he has not paid, the procedural burden is on the attorney. 
permit such access. While the courts might be willing to impose this additional penalty upon an errant attorney-at least in the case of a clear or avoidable breach of ethical duty ${ }^{25}$-courts may be expected to be more reluctant to impose further costs upon the client. The Seventh Circuit, for example, has expressed concern that denial of access to the work product "is a real penalty for the client," and that it is an undesirable one when imposed "irrespective of any fault on the part of the party litigant."26 Since in most instances the loss will be divided between client and attorney, courts should decide the work-product access question so as not to harm an innocent client any more than is necessary to serve the purposes of the $A B A$ Code of Professional Responsibility.

\section{The Policies of Disqualification and Their Bearing on Work- Product AcCEss}

The ABA Code of Professional Responsibility ${ }^{27}$ seeks to promote public trust in the bench and bar, as well as to protect clients and litigants from injury arising from specific ethical violations. A court may impose disqualification either as a sanction against an attorney who has violated the Code, in order to deter unethical behavior and maintain public confidence in the bar, or as a remedy for the party who has been disadvantaged by the attorney's violation. When an attorney has breached the confidences of a client, for example, disqualification may serve both as a sanction and as a remedy. Even in the absence of injury to a particular litigant, however, sanctions including disqualification may be imposed on attorneys whose conduct could tarnish the reputation of the profession. ${ }^{28}$ Whether sub-

${ }^{25}$ Where the lawyer's breach was not deliberate, and he took reasonable precautions to avoid the ethical problem, increasing the penalty by denying his successor access to his work product would serve no purpose. So long as disqualification may be granted for mere "appearances of impropriety," there will be disqualified attorneys whose conduct was basically innocent.

24 First Wis. Mortgage Trust v. First Wis. Corp., 584 F.2d 201, 205 (7th Cir. 1978) (en banc).

${ }^{27}$ Some states may have rules that differ in some respects, e.g., rules promulgated under CaL. Bus. \& Pror. Code $\$ 6076$ (West 1974). This comment focuses for the most part on federal appellate decisions based on the ABA Code. Where state decisions differ or better illustrate the problems involved in the inquiry, they will be noted. State decisions are collected in Annot., 28 A.L.R.3d 389 (1969); Annot., 17 A.L.R.3d 835 (1968); Annot., 52 A.L.R.2d 1243 (1957).

${ }^{23}$ The court's power to disqualify attorneys may derive from the attorney's position as an officer of the court, Ex parte Bradley, 74 U.S. (7 Wall.) 364, 374 (1869), or it may be incidental to the power to admit to practice, Rowen v. LeMans Mut. Ins. Co., 230 N.W.2d 905, 913-14 (Iowa 1975). See ABA Special Comm. on Evaluation of Disctplinary Enforcement, Problems and Recommendations in Disciplinary Enforcement 10-18 (1970). 
stitute counsel should be denied access to work product of disqualified counsel depends on the extent to which such denial is required to further the particular policy served by the disqualification order.

\section{A. Disqualification as a Sanction}

The use of disqualification as a sanction is often found in situations in which Canon 5 ("A Lawyer Should Exercise Independent Professional Judgment on Behalf of a Client") is applicable. ${ }^{29}$ The main purpose of this canon is to guarantee the undivided loyalty of the attorney to his client. Specific disciplinary rules cover such conflicts as adverse financial or personal interests, ${ }^{30}$ the prospect that the lawyer or his associate would be called as a witness, ${ }^{31}$ the acquisition of a proprietary interest in the litigation, ${ }^{32}$ and the transaction of outside business with a client..$^{33}$ Most significant are the provisions of Disciplinary Rule 5-105, which concern the lawyer's representation of the interests of multiple clients. A lawyer must decline multiple employment that might impair the exercise of his independent professional judgment or involve him in representing differing interests unless it is obvious that he can adequately represent each client and the clients agree to the multiple representation after disclosure of the possible effects on the attorney's independent judgment. ${ }^{34}$

The scope and purpose of Disciplinary Rule 5-105 were considered in IBM v. Levin. ${ }^{35}$ IBM moved for disqualification of plaintiff's counsel on a theory of concurrent representation. Prior to and during the pendency of plaintiff's antitrust suit against IBM, an attorney in IBM's legal department had contacted a member of plaintiff's firm regarding a series of discrete and unrelated labor problems. On the basis of this representation, IBM moved for disqualification in the antitrust suit. The motion was granted by the district court and affirmed by the Second Circuit.

The court of appeals acknowledged that IBM was not injured in its capacity as a litigant in the antitrust suit, ${ }^{36}$ and indeed that

\footnotetext{
20 ABA Code of Professional Responsibitity, Canon 5 (1975).

${ }^{30}$ Id., DR 5-101(a).

${ }^{31}$ Id., DR 5-101(B), 5-102. See International Elec. Corp. v. Flanzer, 527 F.2d 1288, $1290-$
}

95 (2d Cir. 1975).

${ }^{32}$ ABA Code of Professional ResponstbitTy, DR 5-103 (1975).

33 Id., DR 5-104.

4 Id., DR 5-105.

3s 579 F.2d 271 (2d Cir. 1978).

35 Id. at 283. 
any possiblity of injury was eliminated by IBM's dismissal of the firm in the labor matters. ${ }^{37}$ Although a Canon 5 violation of this sort may cause injury to the client, ${ }^{38}$ IBM's disqualification motion appears incongruous since the infraction in this case would have tended to injure Levin, the plaintiff, not IBM. ${ }^{39}$ But, the court noted, "[t]he plaintiff"s interest in retaining counsel of its choice and the lack of prejudice to IBM resulting from [the attorney's] violation of professional ethics are not the only factors to be considered in this disqualification proceeding." 40 Also to be considered is the "maintenance of the integrity of the legal profession and its high standing in the community." 41 The public's sense of fair play is surely offended by an attorney who purports to serve both sides in a conflict. Disqualification, therefore, "is primarily justified as a vindication of the integrity of the bar."

The concept of disqualification as a sanction against unseemly, even if harmless, behavior reaches fullest expression in cases involving Canon 9 ("A Lawyer Should Avoid Even the Appearance of Professional Impropriety.").43 This canon has been invoked to compel disqualification for the appearance of a violation of the other canons, on the theory that conduct, even though ethical, may appear unethical to the public. ${ }^{44}$ As in the case of Canon 5 disqualifica-

${ }^{37}$ Id. at 282-83. Plaintiffs argued that IBM was not injured by the simultaneous representation because of the termination of that representation and the trial court finding that the firm did not obtain any information which could be used against IBM in the antitrust suit. The court did not dispute this, but predicated the disqualification on the need to promote public confidence in the bar.

33 The firm might not pursue the litigation as vigorously as possible for fear of offending a client in other matters. Id. at 280. See also Cinerama 5, Ltd. v. Cinerama, Inc., 528 F.2d 1384 (2d Cir. 1976), cited in IBM v. Levin, 579 F.2d at 280.

39 IBM might be considered injured in its labor law matters, but disqualification of the plaintiff's firm in the antitrust suit does not remedy this injury. Either IBM could discharge the firm-which it did-or it could retain the firm. In the latter instance, it is unlikely that procuring the firm's disqualification in another matter would serve to restore the firm's undivided loyalty.

to 579 F.2d at 283 .

"Id.

12 Id. In a situation in which one party is harmed and the other party is left no better off by a court action, it might be questioned whether the public would agree that the "integrity of the bar" should be "vindicated" at the expense of the litigants. See Woods v. Covington County Bank, 537 F.2d 804, 812-13 (5th Cir. 1976).

13 ABA Code of Professional Responsibility, Canon 9 (1975).

4 See Kramer v. Scientific Control Corp., 534 F.2d 1085, 1090-91 (3d Cir.), cert. denied, 429 U.S. 830 (1976); W.E. Bassett Co. v. H.C. Cook Co., 302 F.2d 268, 269 (2d Cir. 1962) (per curiam); Note, Ethical Considerations When an Attorney Opposes a Former Client: The Need for a Realistic Application of Canon 9, 52 CHI.-KENT L. REv. 525 (1975). See also ABA Comm. on Proressional Ethics, Informat OpINion No. 885 (1965) ("the lawyer should avoid representation of a party in a suit against a former client, where there may be the appear- 
tion, the policy served is not protection of the attorney's adversaries in subsequent litigation, but preservation of the integrity of the profession from the appearance that the interests of a party are being compromised or that the judicial process itself is tainted in any way.

In the absence of a possibility of prejudice to the disqualified attorney's present or former client arising from his ethical violation, a disqualification order may serve three purposes: deterrence of future ethical violations by the attorney and other members of the bar, protection of the court itself from ethical taint, and maintenance of the profession's public image. Whether disqualification should be complemented by an order denying substitute counsel access to his predecessor's work product depends on whether such an order will advance these purposes.

1. Deterrence. To the extent that the economic burden of the denial of access to work product is borne by the errant attorney, ${ }^{45}$ such an order will increase the penalty for ethical infractions. ${ }^{46}$ To that extent, therefore, such an order may be justified. The additional deterrence, however, is created at the cost of punishing the attorney's client as well. Assuming that the client was not at fault in the lawyer's breach of professional ethics, this punishment is unfair. Moreoever, the additional deterrent effect of this added penalty is not likely to outweigh the added hardship it imposes on the client. The stigma of disqualification alone probably suffices to

ance of a conflict of interest or a possible violation of confidence, even though this may not be true in fact"). But see Woods v. Covington County Bank, 537 F.2d 804, 813 (5th Cir. 1976); International Elec. Corp. v. Flanzer, 527 F.2d 1288, 1295 (2d Cir. 1975); Redd v. Shell Oil Co., [1974-2] Trade Cas. If 75,392 at 98,278 (D. Utah), rev'd on other grounds, 518 F.2d 311 (10th Cir. 1975); Comment, supra note 18, at 459.

Disqualification may also result from a violation of Disciplinary Rule 9-101, which prohibits a former government attorney from subsequently accepting private employment in regard to a matter for which he had "substantial responsibility" while in government service. ABA Code of Professional Responsibility, DR 9-101. The policy behind the rule is not protection of the party's adversaries, but preservation of the integrity of the profession from the appearance that government service is being manipulated for private gain. See Central Milk Producers Coop. v. Sentry Food Stores, Inc., 573 F.2d 988, 990 (8th Cir. 1978) (dictum); General Motors Corp. v. City of New York, 501 F.2d 639, 650 (2d Cir. 1974). But cf. Allied Realty v. Exchange Nat'l Bank, 283 F. Supp. 464, 466 (D. Minn. 1968), aff'd, 408 F.2d 1099 (8th Cir. 1969) (suggesting the need to protect the opposite party from this misuse of information gained during government employment). Woods v. Covington County Bank, 537 F.2d 804 (5th Cir. 1976), contains a discussion of both these rationales for the rule. Id. at 814-18.

${ }^{15}$ See text and notes at notes 19-26 supra.

${ }^{4}$ But see First Wisconsin, 584 F.2d at 209. The court said that denial of access to work product "would in no way discipline disqualified counsel whose actions have been the cause of the disqualification order." The court assumed that the client would bear the full cost. Id. 
deter most avoidable breaches: ${ }^{47}$ as in the criminal law, the speed and certainty of punishment tend to provide more effective deterrence than an increase in penalties. ${ }^{48}$

A further consideration is the propriety of the courts judging disqualification orders primarily with a view to deterrence. The Second Circuit has noted that "[t]he business of the courts is to dispose of litigation and not to act as general overseer of the ethics of those who practice here unless the questioned behavior taints the trial of the cause before it." 49 The principal instrument for the enforcement of professional ethics must be the grievance committees of the bar. .0 $^{5}$

2. Protection of the Court. Attorneys serve as officers of the court; their behavior reflects upon the court and can materially affect the quality of justice meted out. Consequently, even in the absence of particular injury to litigants, courts have an interest in removing from their positions as officers those attorneys whose conduct they consider ethically censurable. It might also be argued that the court has an interest in expunging from its records and processes the tainted work product of the wayward lawyer. On this ground, it might be necessary to deny access to the disqualified attorney's

47 Part of the deterrence may stem from the disappointed client. Professor Hazard has suggested that

[t]he clients [of] large corporate firms are relatively sophisticated about conflicts and reasonably tolerant of wholly unforeseeable ones. But they are also in a position to wreak heavy retribution if their affairs become involved in a conflict they think should have been avoided. . . . Word of the client's dissatisfaction can spread through the corporate grapevine, resulting in permanent damage to the firm's reputation and the reputation of its members and associates.

G. HAZARD, supra note 1 , at 82.

18 See Andenaes, The General Preventive Effects of Punishment, 114 U. PA. L. Rev. 949, 961.62 (1960).

" W.T. Grant Co. v. Haines, 531 F.2d 671, 677 (2d Cir. 1975); accord, Board of Educ. v. Nyquist, 591 F.2d 1241, 1246 (2d Cir. 1979); Lefrak v. Arabian Am. Oil Co., 527 F.2d 1136, 1141 (2d Cir. 1975). Even Judge Castle, who dissented from a decision granting access to work product, agreed that deterrence is not the purpose of the order: "[T]he purpose of denying access to the work is not to penalize the defendants but, more importantly, to protect the plaintiffs specifically and the public generally." 584 F.2d at 221 n.16 (Castle, J., dissenting in part, concurring in part).

so Board of Educ. v. Nyquist, 591 F.2d 1241, 1246-48 (2d Cir. 1979); Lefrak v. Arabian Am. Oil Co., 527 F.2d 1136, 1141 (2d Cir. 1975); Van Graafeiland, Lawyers' Conflict of Interest-A Judge's View, pt. II, 178 N.Y.L.J. 13, 22, col. 2 (July 20, 1977). In his most recent State of the Judiciary address to the American Bar Association, Chief Justice Burger commented on the methods by which professional misconduct may be punished, listing as appropriate sanctions "reprimand, censure, suspension or disbarment." Annual Address to the American Bar Association on the State of the Judiciary 4 (Feb. 11, 1979). Although the Chief Justice noted that both courts and bar associations have a role to play, his emphasis was on discipline; disqualification proceedings were not mentioned in this respect. 
work product. Where the ethical breach gave disqualified counsel no prejudicial advantage over his opponent in the litigation, however, his work product will be no better or worse-or more tainted-than the work product of any other attorney of comparable talent in his position. Moreover, if substitute counsel, by investing time and resources, can duplicate the work, the challenged work product cannot be said to be tainted. If the work itself is untainted, then the moving party's only benefit from procuring the order denying access will be the increase in cost and inconvenience to his opponent-a benefit that need not be conferred in order to protect the integrity and quality of the judicial system.

3. Appearances of Propriety. Since one purpose of a disqualification order is to maintain public confidence in the integrity of the profession, it might be argued that denial of access to the errant attorney's work product is also needed. An unsophisticated public might not distinguish between tainted and untainted work product and might consider the continued use of either as an injustice. Although no one knows with certainty what reaction the public may have to the occurrences in the courtroom, ${ }^{51}$ as the prejudice to individual litigants disappears it may be expected that the public's interest correspondingly wanes. The public's concern is, after all, that the litigants receive fair treatment. In the absence of evidence of prejudice, it seems unlikely that the public will inquire any deeper. On the contrary, it seems more likely that, as the Fifth Circuit has commented, "the more frequently a litigant is delayed or otherwise disadvantaged by the unnecessary disqualification of his lawyer . . . , the greater the likelihood of public suspicion of both the bar and the judiciary." 52 Where the client of the disqualified attorney is subjected to further delay and expense without any redeeming protection of the opposing party's rights, public esteem is more likely to decrease than increase.

Denial of access to untainted work product does not, therefore, substantially further any of the purposes of the disqualification policy, although it does inflict substantial "punishment" on the client of the disqualified attorney. In such instances, access to the work product should not be denied. The results reached by the few courts confronted with this question, though short on analysis, are consistent with this conclusion. ${ }^{53}$ For example, the court in International

s'But see First Wis. Mortgage Trust v. First Wis. Corp., 584 F.2d at 220 (Castle, J., dissenting in part, concurring in part) (Judge Castle was willing to speculate that the average person would "not approve of allowing disqualified counsel's work to be used against its former client on the facts of this case.").

52 Woods v. Covington County Bank, 537 F.2d 804, 813 (5th Cir. 1976).

s3 See cases cited in note 3 supra. 
Business Machines Corp. v. Levin ${ }^{54}$ rejected IBM's argument that the plaintiff should be denied access, saying, "the district court ameliorated the harsh effect upon the plaintiffs of its sanction against [their counsel] by permitting the turnover to substitute counsel ... of the past work product." ${ }^{.55}$

\section{B. Disqualification as a Remedy}

Although disqualification under Canons 5 and 9 does not appear necessarily to require denial of access to work product, not all cases of disqualification are free of danger of prejudice to the moving party. Indeed, under the most common ground for disqualification, Canon 4 ("A Lawyer Should Preserve the Confidences and Secrets of a Client"), ${ }^{56}$ the moving party faces the prospect that the confid-

s 579 F.2d 271 (2d Cir. 1978).

so Id. at 283. In arguing for denial of access, IBM had relied on the panel decision in First Wis. Mortgage Trust v. First Wis. Corp., 571 F.2d 390, vacated, 584 F.2d 201 (7th Cir. 1978) (en banc). The Second Circuit court noted:

To the extent that the Seventh Circuit Court of Appeals lays down a legal tenet in First Wisconsin Mortgage Trust against permitting the turnover of a disqualified attorney's work product, we disagree, but we note that the court in that case expressly limited its holding to the facts of that case.

579 F.2d at 283 (citation omitted). The two decisions were not incompatible. Judge Castle's opinion for the majority in the panel decision in First Wisconsin analyzed the case in terms of possible prejudice to the moving party through disclosure of confidential information by their former counsel. The $I B M$ court, considering a situation in which disqualification was justified as a sanction rather than as a remedy, would have been quite correct in finding the first decision in First Wisconsin inapplicable in a Canon 5 case. The en banc majority in First Wisconsin was able to characterize the facts as not posing the problem of confidentiality, and in part relying on the IBM decision, $584 \mathrm{~F} .2 \mathrm{~d}$ at $207-08$, reached a decision contrary to that of the panel and allowed access.

36 ABA Code of Professional. Responsibitity, Canon 4 (1975). Disciplinary Rule 4-101(A) defines "confidence" as "information protected by the attorney-client privilege under applicable law," and "secret" as "other information gained in the professional relationship that the client has requested be held inviolate or the disclosure of which would be embarrassing or would be likely to be detrimental to the client." Ethical Consideration 4-4 emphasizes that the ethical obligation of the lawyer is broader than the attorney-client privilege and exists "without regard to the nature or source of information or the fact that others share the knowledge."

Neither the Code of Professional Responsibility nor the cases interpreting it make any significant distinction between the concepts of "confidence" and "secret." This comment therefore employs the terms interchangeably. The argument of one commentator, that analysis of the work-product problem requires separate consideration of "secrets" and "confidences," Note, supra note 20, at 1058-59, 1063, should be rejected. This argument would permit the conclusion that information imparted to a lawyer during the course of legal representation is not protected by Canon 4 if it technically falls outside the attorney-client privilege (thereby being disqualified as a "confidence") but was nevertheless directly transferred by the client (thereby falling outside the Note's concept of a "secret" as having been obtained "from sources other than the client," $i d$. at $1058 \&$ n.25). This conclusion is directly 
ences he entrusted to a former attorney may be used against him by an opposing party. Canon 4 disqualifications share with those already discussed ${ }^{57}$ the purposes of deterring unethical behavior, protecting the courts from tainted proceedings, and maintaining public confidence in the bar. In addition, however, Canon 4 disqualifications serve to protect the former client from the effects of his erstwhile lawyer's ethical breach. Courts have generally recognized that, over and above any desire to "vindicate the integrity of the bar," the principal purpose of disqualification in these cases is to serve as a remedy for the breach of the confidential relationship..$^{58}$ A guarantee that information passed to an attorney will remain confidential is vital to the attorney-client relationship. ${ }^{59} \mathrm{~A}$ client must be willing to supply to his attorney all information conceivably related to his case, lest the adversary system operate on less than the fullest complement of available information. To protect this confidence even after the attorney-client relationship has ended, the provisions of Canon 4 must be strictly enforced, so that a client need not fear "that confidences conveyed to his attorney in one action will return to haunt him in a later one."80

This concern with specific injury to the former client is reflected in the test most commonly invoked for disqualification under Canon 4: the "substantial relationship" test. ${ }^{61}$ If the attorney's former client can show that the present litigation involves matters

contrary to the quoted intention of Ethical Consideration 4-4 that the ethical obligation be broader than the attorney-client privilege, and also contrary to the consistent practice of the courts. See, e.g., NCK Organization Ltd. v. Bregman, 542 F.2d 128, 133 (2d Cir. 1976).

${ }^{57}$ See text and notes at notes 45-55 supra.

s8 See, e.g., Board of Educ. v. Nyquist, 590 F.2d 1241, 1246 (2d Cir. 1979). Some courts have suggested that such breaches are the only appropriate ground for disqualification. Fred Weber, Inc. v. Shell Oil Co., 566 F.2d 602, 608 (8th Cir. 1977), cert. denied, 436 U.S. 905 (1978); Ceramco, Inc. v. Lee Pharamaceuticals, 510 F.2d 268, 271 (2d Cir. 1975) (characterizing disqualification as a "remedy"). In some instances disqualification is appropriate as a remedy even though there is no danger of breach of confidence. Kroungold v. Triester, 521 F.2d 763 (3d Cir. 1975) (disqualification denied on the basis of DR 5-101(B)). See also E.F. Hutton \& Co. v. Brown, 305 F. Supp. 371, 376-77 (S.D. Tex. 1969) (suggesting that only a former client can bring a disqualification motion).

50 Canon 4's Ethical Consideration 4-1 provides: “The observance of the ethical obligation of a lawyer to hold inviolate the confidences and secrets of his client not only facilitates the full development of facts essential to proper representation of the client but also encourages laymen to seek early legal assistance." See also Liebman, supra note 2 at 999.

${ }^{60}$ Richardson v. Hamilton Int'l Corp., 469 F.2d 1382, 1384 (3d Cir. 1972).

s1 E.g., Westinghouse Elec. Corp. v. Gulf Oil Corp., 588 F.2d 221, 223-25 (7th Cir. 1978); American Roller Co. v. Budinger, 513 F.2d 982, 984-85 (3d Cir. 1975); Emle Indus., Inc. v. Patentex, Inc., 478 F.2d 562 (2d Cir. 1973). This test was first applied by a federal district court in T.C. Theatre Corp. v. Warner Bros. Pictures, Inc., 113 F. Supp. 265 (S.D.N.Y. 1953). See Liebman, supra note 2, at 1001-04; Note, Attorney's Conflict of Interests: Representation of Interest Adverse to That of Former Client, 55 B.U.L. REv. 61, $73-75$ (1975). 
"substantially related" to the subject matter of a prior representation, the courts will presume the passing of confidential information, ${ }^{82}$ and disqualification will ensue. It is thought that by removing the attorney from the case he will not be able to use the confidential information-either consciously or unconsciously-against the former client. Disqualification alone may not adequately protect the former client, however, if the attorney has used information acquired during the former representation in preparing the case. After disqualification, substitute counsel might benefit from the disqualified attorney's special insight and inside information as reflected in his work product and the former client would still be haunted by his revealed confidences. Disqualification must therefore be accompanied by a denial of access to the tainted work product and substitute counsel must make a fresh beginning.

The need to deny substitute counsel access to work product may be seen most starkly in cases such as Doe v. A Corp. ${ }^{63}$ where knowledge of the existence of a cause of action itself depended upon illicit information supplied by a former attorney. In that case, the full record, including the pleadings, was sealed in order to protect the former client..$^{64}$ In the more common Canon 4 case, such as Edilcentro International, Ltd. v. Porco, ${ }^{65}$ there is no dispute over the

62 The attorney may not avoid disqualification by claiming that he did not have access to confidential information or that no secrets were divulged to him. Were the rule otherwise, it "would require the disclosure of the very matters intended to be protected" in order for the movant to procure disqualification. T.C. Theatre Corp. v. Warner Bros. Pictures, Inc., 113 F. Supp. 265, 268-69 (S.D.N.Y. 1953); accord, Schloetter v. Railoc of Ind., Inc., 546 F.2d 706, 710 (7th Cir. 1976); Hull v. Celanese Corp., 513 F.2d 568, 572 (2d Cir. 1975).

Knowledge obtained through a prior representation will also be imputed to partners and associates in the firm. See Westinghouse Elec. Corp. v. Kerr-McGee Corp., 580 F.2d 1311, 1321 (7th Cir.), cert. denied, 99 S. Ct. 353 (1978); Laskey Bros. v. Warner Bros. Pictures, 224 F.2d 824, 826-27 (2d Cir. 1955), cert. denied, 350 U.S. 982 (1956); Township Bd. v. Lewis, 234 N.W.2d 815, 819 (Minn. 1975). This "risk twice removed" has been criticized by some commentators, e.g., Liebman, supra note 2, at 1000-01; Note, Unchanging Rules in Changing Times, 73 Yale L.J. 1058 (1964). The Second Circuit has apparently recognized the difficulties the strict rule has created for large-firm practice; accordingly, the court has now made this presumptive imputation rebuttable. See Silver Chrysler Plymouth, Inc. v. Chrysler Motor Corp., 518 F.2d 751, 754-57 (2d Cir. 1975); Note, supra note 2, at 145-48.

'3 330 F. Supp. 1352 (S.D.N.Y. 1971), aff'd per curiam sub nom. Hall v. A. Corp., 453 F.2d 1375 (2d Cir. 1972). Doe concerned an attorney who was discharged from a law firm which was counsel to " $A$ " Corp. Before the discharge. he purchased one share of the defendant's stock, so that he could later file a stockholder's derivative suit on the basis of information he had learned as its lawyer. The district court found a violation of Canon 4, disqualified "Doe," and enjoined him from acting as counsel in any similar action or otherwise disclosing any information he had gained during the course of his former employment.

"Id. at 1356.

is No. 75-6488 (S.D.N.Y. Dec. 8, 1978). 
pleadings and court papers; ${ }^{68}$ the work product in question is more likely to be the extensive preparatory work of the attorney prior to disqualification. In cases of this sort, the denial of access to work product is directly related to the purpose served by disqualification. Although problems of characterizing the ethical breach and the extent of taint in the work product remain, a guiding principle is established: work-product access should be granted except where such access would compromise the protection sought to be afforded by the disqualificaton order itself.

\section{The Problems of Characterization}

If violations of the canons divided neatly into specific categories, the question of access to work product would be somewhat simpler, although a significant problem would remain in identifying any untainted work product produced in the course of a representation posing the problem of breaches of confidence.$^{67}$ Bright-line distinctions between violations would facilitate the process by allowing the courts to categorize work product cases pursuant to a simple rule: in the event of a Canon 4 violation, work product must be suppressed; in the event of other violations, work product may pass to substitute counsel. In the Doe case, a motion for access to work product would be denied; ${ }^{68}$ in the Levin case, it would be granted. ${ }^{69}$ Unfortunately the distinctions are not always so clear-cut. Courts are often faced with ethical violations for which the identification of the applicable canon does not solve the question of work-product access. In such cases, the courts must undertake a careful inquiry into the nature of the conflicting representations, in order to deny access to work product only if there is a significant prospect that confidences or secrets might be revealed.

1. Fund of Funds. In Fund of Funds, Ltd. v. Arthur Andersen $\&$ Co., ${ }^{70}$ the Second Circuit faced an ethical problem arising from "unusual facts"71 on the boundary of Canons 4 and 5. The New York office of the law firm of Morgan, Lewis \& Bockius ("MLB"), a longtime regional counsel to Arthur Andersen \& Co., was engaged by a Canadian liquidator as United States counsel in litigation arising from the fraud and mismanagement of the notorious Fund of

\footnotetext{
"Id., slip op. at 2.

67 These problems are considered in Part III infra.

${ }^{68}$ See text and notes at notes 63-64 supra.

69 See text and notes at notes 35-42 supra.

70567 F.2d 225 (2d Cir. 1977).

${ }^{71} \mathrm{Id}$. at 226.
} 
Funds. It soon became apparent that the Fund might have a cause of action against Arthur Andersen, which had served as auditor of the Fund. MLB painstakingly avoided contact with the case against Arthur Andersen by suing other defendants separately and by doing a "disappearing act"72 when discussions with other counsel turned to the Arthur Andersen matter. Nevertheless, MLB selected or assisted in the selection of the firm of Milgrim, Thomajan \& Jacobs, with which it had worked on related matters, to handle the Fund's suit against Arthur Andersen. MLB also passed along to the Fund's Canadian solicitor any information concerning Arthur Andersen that was "really hot," sent an associate to Milgrim, Thomajan to review and revise the complaint against Arthur Andersen, and conducted certain studies and interviews jointly with Milgrim, Thomajan. ${ }^{73}$ The district court held that MLB would have been disqualified had the firm attempted to represent the Fund directly, but that Milgrim, Thomajan need not be disqualified. It also denied Arthur Andersen's motion to dismiss the complaint with prejudice and to suppress certain evidence as tainted by the involvement of MLB. ${ }^{74}$

The Court of Appeals held that Milgrim, Thomajan was subject to disqualification on both Canon 4 and Canon 5 grounds. ${ }^{75}$ Under Canon 5, the court viewed Milgrim, Thomajan's activity as aiding and abetting MLB's breach of its duty of undivided loyalty to Arthur Andersen. Essentially, MLB attempted "to violate by indirection those very strictures it cannot directly contravene." Canon 4, the court reasoned that by virtue of the close relation between the attorneys, Milgrim, Thomajan was "in a position to receive relevant confidences regarding Andersen." "77

The court, though mandating disqualification of Milgrim, Thomajan, affirmed the district court's denial of Arthur Andersen's request for ancillary relief, which included suppression of the work product collected by Milgrim, Thomajan and by MLB. ${ }^{78}$ The court purported to "strike a delicate balance between the Fund's interest in representation by counsel of its choice and the need to maintain high ethical standards within the profession of law." 79 The court's

${ }^{72}$ Id. at 230.

${ }^{73}$ Id. at $229,231-32$.

"Fund of Funds, Ltd. v. Arthur Andersen \& Co., 435 F. Supp. 84 (S.D.N.Y.), rev'd in part, aff'd in part, 567 F.2d 225 (2d Cir. 1977).

${ }^{75} 567$ F.2d at 233.

"Id.

II Id. at 235 .

${ }^{78}$ Id. at $236-37$.

"Id. 
determination thus apparently was based on a view of disqualification as a sanction rather than as a remedy to protect the aggrieved former client.

In approving access to work product, the court relied on W.T. Grant Co. v. Haines, ${ }^{80}$ a case involving Disciplinary Rule $7-104,{ }^{81}$ the prohibition of direct contact between an attorney and the opposing party. The W.T. Grant court had stated: "While disqualification is clearly punitive insofar as Grant and its outside counsel are concerned, its benefit to Haines is indeed questionable." ent is quite inapposite in Fund of Funds, in which the court found serious danger of prejudice to Arthur Andersen, which it sought to remedy by disqualification. Moreover, the Fund of Funds court, again citing W.T. Grant, described the proposed denial of access to work product as affecting the outcome of the litigation-a result the court was "loathe to countenance." 83 Yet it is precisely such tainted work product as might affect the outcome that should be suppressed. The Fund of Funds case thus illustrates the danger of confusing the grounds for disqualification: its result may be questioned as it was reached on the basis of an analysis of disqualification as a sanction and of precedent involving no danger of prejudice to the moving party.

2. First Wisconsin. The importance of alternative characterizations was even more strikingly illustrated by the decision in First Wisconsin Mortgage Trust $v$. First Wisconsin Corp. ${ }^{84}$ The case involved a dispute over extensive analyses of some 300 real estate loan transactions prepared by fifteen lawyers associated with defendant's counsel, Foley \& Lardner, over a period of more than a year. Foley was disqualifed from the action on the basis of its former representation of the plaintiff. ${ }^{85}$ The district court denied substitute counsel's motion for access to the Foley work product; ${ }^{86}$ a panel of the Seventh Circuit affirmed; ${ }^{87}$ finally, rehearing the case en banc, the Seventh Circuit reversed the district court, ${ }^{88}$ with the author of

${ }^{80} 531$ F.2d 671 (2d Cir. 1976).

81 ABA Code of Professional Responsibility, DR 7-104 (1975).

82531 F.2d at 677 .

8s 567 F.2d at 236; cf. Edilcentro Int'l, Ltd. v. Porco, No. 75-6488, slip op. at 11 n.7

(S.D.N.Y. Dec. 12, 1978) (denial of access would not affect outcome).

\& 584 F.2d 201 (7th Cir. 1978) (en banc).

85 First Wis. Mortgage Trust v. First Wis. Corp., 422 F. Supp. 493 (E.D. Wis. 1976).

${ }^{86}$ First Wis. Mortgage Trust v. First Wis. Corp., 74 F.R.D. 625 (E.D. Wis. 1977), rev'd, 584 F.2d 201 (7th Cir. 1978) (en banc).

${ }^{87}$ First Wis. Mortgage Trust v. First Wis. Corp., 571 F.2d 390, vacated, 584 F.2d 201 (7th Cir. 1978) (en banc).

${ }^{8 s}$ First Wis. Mortgage Trust v. First Wis. Corp., 584 F.2d 201 (7th Cir. 1978) (en banc). 
the panel opinion vigorously dissenting..$^{80}$

Foley \& Lardner had served as general counsel to the First Wisconsin Corporation ("First Wisconsin") and its subsidiaries, which included First Wisconsin Mortgage Trust ("Trust"). Among its services to the Trust were the drafting of the "Advisory Agreement" governing the relation between the Trust and its advisor (another subsidiary of First Wisconsin) and "Participation Agreements" governing the relationship between the Trust and First Wisconsin National Bank with regard to real estate loans. ${ }^{90}$ When some of the loans went sour, leading to negotiations between the Trust and First Wisconsin regarding responsibility for the loss, Foley recommended that the Trust procure independent counsel, and the parties continued to negotiate, with Foley representing First Wisconsin. ${ }^{91}$ In March, 1975, the Trust filed suit against First Wisconsin and some of its subsidiaries, alleging violations of rule 10b-5. Two days after the filing, Foley requested the Trust's consent to its continued representation of the defendants, stating in a letter to the Trust that "with the consent of the Mortgage Trust and each of the defendants, there is no ethical or other prohibition that precludes us from representing the defendants in the action." ${ }^{2} 2$ The' Trust declined to consent, requested that Foley withdraw, and in August moved for disqualification..$^{93}$ After a delay of fifteen months, ${ }^{94}$ the district court granted the motion for disqualification, which in turn gave rise to a dispute over access to the work product Foley had amassed.

Although disagreeing on many points of law, the majority and dissent in First Wisconsin agreed that access to work product should "turn on whether there exists a reasonable possibility of confidential information being used in the formation of, or being passed to substitute counsel through the work product in question." ${ }^{95}$ Disagreement hinged on the characterization of the Foley work product. The majority opinion repeatedly asserted that the "routine lawyer work" performed by Foley did not bear "the imprint of confidentially ac-

"Id. at 211 (Castle, J., dissenting in part, concurring in part).

so 422 F. Supp. at 495.

" 584 F.2d at 202.

12422 F. Supp. at 495.

3584 F.2d at 203.

" Id. Apparently the unexplained delay in the disqualification decision was not responsible for the creation of the work product at issue. The loan file analyses were done in 1974 and early 1975, and completed before the motion for disqualification was made. Id.

id. Id 209 (majority opinion) (quoting the dissent); id. at 217 (Castle, J., dissenting in part, concurring in part). 
quired or secret information." isterial nature of Foley's work and plaintiff's failure to claim that the work product might reveal confidential information. ${ }^{97}$ The dissent claimed that there was "a possibility of confidential information being passed through or used to create the work product in this case,"

was generated by Foley \& Lardner with an eye toward the issues of the present suit and was based upon a relationship with both plaintiff and defendants which gave Foley \& Lardner access to the innermost workings of plaintiff's organization and the opportunity to observe first hand the discussion and decisions relevant to the issues in this case. ${ }^{99}$

Both the majority and the dissent accused the other of advocating a per se rule. The majority claimed that the dissent's position would result in automatic denial of access to work product whenever an attorney was disqualified, regardless of whether there was a danger of prejudice arising from the possible use of confidential information. ${ }^{100}$ On the other hand, Judge Castle, dissenting, claimed that the majority set the "near[ly] impossib[le]" requirement that the movant point to a specific breach of confidence to justify a denial of access. ${ }^{101}$ His suggestion that the result reached by the majority constituted a per se rule seems to have depended mainly on his conclusion that the general counsel relationship that had existed between Foley and the Trust presented the problem of confidentiality in its most egregious form. Allowing access in such a case, he reasoned, would lead lower courts to be wary of denying access in "the more common case, [in which] the disqualified law firm was not generally counsel to both parties and involved in the very transactions at issue."102

The majority's position depended on its view of disqualification as a sanction. Apparently convinced that the protective purpose of

96 Id. at 210 (majority opinion).

${ }^{97}$ Id. In addition, the majority argued that counsel for the Trust conceded in oral argument that the work product did not reveal any confidences. Id. As the dissent pointed out, this concession was limited to the statement that the work product did not contain information subject to the attorney-client privilege in the technical evidentiary sense. Id. at 212 (Castle, J., dissenting in part, concurring in part).

${ }^{98} 584 \mathrm{~F} .2 \mathrm{~d}$ at 223 (Castle, J., dissenting in part, concurring in part).

"Id. at 217-18 (footnote omitted).

${ }^{100}$ Id. at 208-09 (majority opinion). Judge Pell, author of the en banc majority opinion, had complained in his earlier panel opinion dissent that Judge Castle's approach "amounts to a per se rule." 571 F.2d at 399 (Pell, J., dissenting).

${ }^{101} 584$ F.2d at 222 (Castle, J., dissenting in part, concurring in part).

${ }_{102} I d$. 
Canon 4 would not be served by denial of access to the work product involved, the court did not even mention the canon, even though it had apparently served as the basis of the initial disqualification order. ${ }^{103}$ The majority was able to conclude that denying access "would in no way discipline disqualified counsel whose actions have been the cause of the disqualification order,"104 implying that the only purpose of the proceeding was disciplinary rather than protective. The majority opinion approvingly cited International Business Machines Corp. v. Levin for the proposition that "disqualification in circumstances such as these where specific injury to the moving party has not been shown is primarily justified as a vindication of the integrity of the bar." 105

Judge Castle's dissent emphasized that "the purpose of denying access to the work is not to penalize the defendants but, more importantly, to protect the plaintiff specifically and the public generally." ${ }^{108}$ Finding disqualification in this case to be grounded upon Canon 4's protective policies, he could not so easily dismiss the notion that denial of access to work product was required in order to protect the Trust. He suggested that Foley could have used the insights it gained through being present during the questioned transactions to determine what facts in the loan files were important and should be highlighted. ${ }^{107}$ Whether or not this danger justifies denial of access, ${ }^{108}$ the dissent plainly exposes the failure of the majority to articulate adequately the purpose for the disqualification of Foley and the relation of the work product to that purpose.

103 The precise ground for the disqualification order is a matter of some confusion. The district court applied the "substantial relation" test, see text at note 62 supra, thus implying that Canon 4 was violated. The court, however, did not mention Canon 4, nor did it discuss the possibility of breach of confidence. In its subsequent order denying access to the work product, the district court did discuss the importance of protecting a client's confidences, 74 F.R.D. at 626, but relied more strongly on the importance of preserving "the confidence that a client has in his attorney." Id. As the court's rhetorical question-"What greater violation of confidence could there be than for that attorney in a subsequent court proceeding to actively represent interests opposed to those of his former client?", id. at 627-shows, the court's focus was upon the adverse representation rather than upon the breach of confidence. The court concluded that "there is little or no point in the initial disqualification" without denial of access to work product, $i d$., thus implying that the denial was unrelated to any concern for the protection of confidential information.

104584 F.2d at 209 (majority opinion).

10s Id. at 208 (quoting IBM v. Levin, 579 F.2d 271, 283 (2d Cir. 1978)). Judge Castle rightly distinguished Levin. Id. at 216 n.6. See also rote 37 supra.

${ }^{106}$ Id. at $221 \mathrm{n.16}$ (Castle, J., dissenting in part, concurring in part).

in Id. at 218.

tos See text and notes at notes 109-111 infra. 


\section{Presumptions and Burdens of Proof}

When the purpose of disqualification is protection of the former client or current adversary, further intervention by the court may be necessary to shield the former client from the possible prejudicial effect of substitute counsel's use of the disqualified attorney's work product. Because of the cost to his opponent and the opportunity for litigious gamemanship, however, the remedy afforded must be carefully limited to that legitimately required for the former client's protection.

\section{A. The Presumption of Taint}

Appellees in the First Wisconsin case urged, ${ }^{109}$ and at least one court has suggested, ${ }^{110}$ that disqualification for breach of Canon 4 , or other violation of the confidential attorney-client relationship, must necessarily be accompanied by a denial of access to work product. Such an approach views work product as part of the wrongful representation, as an embodiment of the breach of confidence. Under this view, it can be argued that the "substantial relation" presumption applied in making the disqualification decision should be extended to presume that the work product is tainted.

There are at least three reasons to reject this course. First, although the possession of confidential information may be presumed from prior representation in a substantially related matter, it does not follow that all work product-no matter how routine or unrelated to the subject of the prior representation-is based upon such confidences. Realistically, many items of work product present little, if any, prospect of taint. ${ }^{111}$ Second, if the court presumes that all work product is tainted, it must suppress the pleadings, motions, court papers, and discovery materials prepared or obtained by the disqualified attorney, and the client must start afresh. ${ }^{112}$ Indeed,

tos Brief for Appellee at 22, First Wis. Mortgage Trust v. First Wis. Corp., 571 F.2d 390, vacated, 584 F.2d 201 (7th Cir. 1978) (en banc).

${ }^{110}$ See Edilcentro Int'l, Ltd. v. Porco, No. 75-6488 (S.D.N.Y., Dec. 12, 1978).

III Even Judge Castle admitted that the possibility of confidences being used to the disadvantage of the former client may be "miniscule" for some work product. 584 F.2d at 216 (Castle, J., dissenting in part, concurring in part). See also id. n.8.

"12 Some courts have argued that the work product of the disqualified attorney should be distinguished from the primary documents the attorney collected through discovery or from his client. Edilcentro Int'l, Ltd. v. Porco, No. 75-6488, slip op. at 11 n.7 (S.D.N.Y. Dec. 12, 1978) (distinguishing Fund of Funds); First Wisconsin, 571 F.2d at 398 (panel opinion) (distinguishing Allied Realty of St. Paul, Inc. v. Exchange Nat'l Bank, 408 F.2d 1099 (8th Cir.), cert. denied, 396 U.S. 823 (1969), and E.F. Hutton \& Co. v. Brown, 305 F. Supp. 371 (S.D. Tex. 1969)). This distinction does not withstand careful analysis. There is reason to suspect that an attorney with inside information would be able to frame his discovery requests 
since the attorney may have divulged confidences to his current client, it would logically be necessary to enjoin the client from pursuing a cause of action or defense possibly using tainted materials or information. Ordinarily, no court is likely to impose such a drastic result on one party in order to protect the other. ${ }^{113}$ The trial judge should instead be permitted to exercise discretion in tailoring the order to the facts of each case, deciding which parts of the work product to suppress and which to allow to pass to substitute counsel.

The third argument against applying a presumption of taint to all work product of disqualified counsel is that such a presumption involves an attenuated imputation of improper use of confidences or secrets. The work product may have been created by the errant attorney's associates, themselves not directly privy to the former client's confidences. It is unreasonable to presume that their work product has necessarily been shaped by the knowledge possessed by their colleague. ${ }^{114}$ An anology might be drawn to disqualification itself. Although the partners and associates of the challenged attorney may be disqualified from representing a party adverse to his former client, the presumption is not generally extended a second step. Thus, if a former associate of the errant attorney should join a new firm, that firm is not prohibited from taking the suit. ${ }^{115}$ The danger of the passage of confidential information from a vicariously disqualified attorney is scant, in the event either of his joining a new firm or of his preparing legal work.

Although the courts should not automatically suppress the entire work product of an attorney disqualified under Canon 4, neither should they require the injured party to prove the existence of confidences or secrets in the work product as a predicate to their suppression. Judge Castle in First Wisconsin thought that the majority

and gather primary materials more precisely as a result of that information. Such an advantage might be as significant as his ability to glean the pertinent facts from the documents once collected. Chugach Elec. Ass'n v. United States Dist. Court, 370 F.2d 441, 443 (9th Cir. 1966), cert. denied, 389 U.S. 820 (1967). The work product passed on in Fund of Funds, Allied Realty, and E.F. Hutton is therefore not significantly less prejudicial than that refused in Edilcentro or the First Wisconsin panel opinion.

"1s See W.T. Grant Co. v. Haines, 531 F.2d 671, 677 (2d Cir. 1976) ("The sins of counsel should not be visited upon his client so as to vitiate the latter's cause of action."). Such a result might be justified where the plaintiff would not know of his cause of action were it not for the ethical breach. See Doe v. A Corp., 330 F. Supp. 1352 (S.D.N.Y. 1971), aff'd per curiam sub nom. Hall v. A. Corp., 453 F.2d 1375 (2d Cir. 1972).

it But see Edilcentro Int'l, Ltd. v. Porco, No. 75-6488, slip op, at 6, 8-9 (S.D.N.Y. Dec. 12, 1978).

115 American Can Co. v. Citrus Feed Co., 436 F.2d 1125, 1129 (5th Cir. 1971); Liebman, supra note 2 , at 1000 \& n.18. 
would require such a showing. ${ }^{116}$ As he pointed out, this approach is both unworkable and unfair to the aggrieved party. Determining which items of work product contain confidences would "require a monumental commitment of judicial time."117 Moreover, since "[e]ven the most superficially innocuous document or statement within a document"118 may offer substitute counsel prejudicial insight, the court would be unable to protect adequately against the prospect of such prejudice.

Judge Castle suggested that the court might engage in a caseby-case balancing test, weighing the possibility of prejudice to the former client against the cost to the current client. ${ }^{119}$ Such a formulation, however, provides little practical guidance to the district court facing the work-product-access decision. The two sides of the balance are essentially incommensurable: a necessarily speculative injury based on a possible breach of confidence must be balanced against a more tangible monetary loss from the repetition of legal work. Moreover, interest balancing is particularly difficult because the more extensive is the work product, the greater is the prospect of prejudice to the former client, and also the more onerous is the burden of duplication. In this light the balancing test appears undesirable, providing neither predictable results nor reliable protection to the parties. Finally, the balance is skewed. The decision to allow access to work product is irreversible with respect to the former client (in the absence of appellate relief), while under some circumstances, the current client may be able to recoup his losses by suing his now disqualified attorney. ${ }^{120}$

A better solution is to presume the disputed work product to be tainted, but to allow the party seeking access to rebut this presumption in certain prescribed ways. The burden should be on the party seeking access to prove that there is no substantial likelihood of prejudice to the opposing party from the access, or that the opposing party's actions entitle him to access. If no such proof can be made, access should be denied. ${ }^{121}$

116584 F.2d at 211-13 (Castle, J., dissenting in part, concurring in part). Actually, the majority required that the party opposing access point out to the court "the facets of the relationship which it had had with the disqualified counsel which would somehow give an improper advantage." Id. at 209 (majority opinion). This procedure is obviously quite different from "requiring that specific confidences be found." Id. at 221 (Castle, J., dissenting in part, concurring in part).

${ }^{117}$ Id. at 212 .

"18 Id. at $212-13$.

119 Id. at $220 \mathrm{n} .15$ (Castle, J., concurring in part, dissenting in part).

${ }^{120} \mathrm{Id}$. at 219. See text and notes at notes 20-23 supra.

121 See Liebman, supra note 2, at 1002 n.28. Liebman draws a distinction between two 


\section{B. Rebutting the Presumption of Taint: The Circumstances of the Creation of the Work Product}

To rebut the presumption that the disqualified attorney's work product is tainted, his current client, through substitute counsel, should be allowed to offer proof that the challenged items of work product were prepared under circumstances that show there was no substantial likelihood that the work product reflected confidences of the former client. This approach differs from that advocated by the majority in First Wisconsin, ${ }^{122}$ which placed the burden of proof on the former client, rather than the current client, on the theory that the former client is in "the best possible position to point out to the district court the facets of the relationship" giving rise to prejudice. ${ }^{123}$ Placing the burden on the current client is preferable to the First Wisconsin approach because information concerning the circumstances of the creation of the work product is almost solely within the control of the current client or his disqualified attorney. The nature and contents of the work product, the identity and position of the persons creating it, and the precautions taken to prevent breaches of confidences all are known to the current client, but not to the party opposing access. The former client's special knowledge-the confidences that he revealed ${ }^{124}$-is not pertinent to the

approaches to the evidentiary effect of the presumption. In the first, the fact is presumed only so long as no evidence is submitted in rebuttal-the presumption shifts only the burden of going forward. In the second approach, adopted here, the risk of nonpersuasion would still remain with the party against whom the presumption operated initially-he must prove the nonexistence of the presumed fact.

122584 F.2d at 209. But see Edilcentro Int'l, Ltd. v. Porco, No. 75-6488 (S.D.N.Y. Dec. 30,1977 ) (order for in camera inspection of work product). "Similarly, when examining specific materials for confidential information, the former client seeking to preclude access should enjoy an inference that confidential information is contained therein. Additionally, where there is even a possibility that attorney-client confidences may be manifested within the materials under consideration, access should be denied." Id., slip op. at 8. This approach differs from the proposal in the text in two respects, however. First, it seems to presuppose a need for inspection of the actual documents at this stage of the analysis. Second, it sets an impossibly high standard for access, if the materials are to be suppressed no matter how small the "possibility" that they may contain confidences.

izs 584 F.2d at 209 (majority opinion). When necessary, the court said, the party would be permitted to make in camera submissions concerning what confidences or secrets might have been imparted. Id. The First Wisconsin approach also differs from the approach in the text by focusing on the circumstances surrounding the exchange of confidences rather than the creation of the work product.

${ }^{124}$ In some circumstances, the client may be unaware of the confidences he has imparted to the attorney, especially when the attorney was granted license to inspect any of the client's records that the attorney might consider relevant. Even assuming a prodigious memory and a full appreciation of the legal significance of apparently innocuous information, the assumption that the client's conscious disclosures are coextensive with the former attorney's knowledge seems dubious. 
question whether the work product is likely to reveal those confidences, whatever they may be. The issue will be determined by looking at the process of creating the legal work, not at the actual confidences imparted.

Evidence that might be introduced by a party seeking access would include: an affidavit of documents by the disqualified firm ${ }^{125}$ listing the documents available for access, affidavits or testimony of the attorneys from the disqualified firm describing the production of the work and access of the attorneys actually involved to confidential information or other secrets, and affidavits and testimony regarding the procedures and practices of the firm. Application of the suggested approach and use of this type of evidence might not have changed the result in the First Wisconsin case, however. ${ }^{126}$ Substitute counsel for First Wisconsin could have made a persuasive argument that the loan file analyses in dispute were the product of ministerial work done by junior attorneys who had no access to the confidences of the Trust. It would have been difficult to refute this argument, especially since the Trust's counsel came close to admitting that confidential information was not involved in the dispute. ${ }^{127}$ Even after placing the burden on First Wisconsin rather than the Trust, the court might therefore have been justified in concluding that there was no substantial possibility of the revelation of confidences through access to the Foley work product.

There are certain recurring factual situations in which denial of access is inappropriate: work performed by persons to whom the knowledge of the firm may not realistically be attributed, work performed by persons isolated from exposure to confidences, and rou-

125 An analogy to the British procedure for handling claims of privilege in discovery may prove instructive. The party seeking discovery serves an.interrogatory that is met by an affidavit of all relevant documents from the other party. Objections to particular documents may result in a limited inspection of the material by the court. 4 Moore's Federal Practice II 26.63[2-1], at 26-349 to $26-350$ (2d ed. 1976). In a case involving access to the work product of a disqualified attorney, a similar process might be followed: substitute counsel would request a list of documents, indicating the particular materials sought; the party seeking to prevent access might then object to furnishing documents that he considers likely to be tainted.

${ }^{126}$ Substitute counsel for First Wisconsin relied principally upon the assumption that the nonconfidentiality of the work product was undisputed. Brief for Defendants-Appellants at 29, First Wis. Mortgage Trust v. First Wis. Corp., 571 F.2d 390, vacated, 584 F.2d 201 (7th Cir. 1978) (en banc). Substitute counsel did not discuss the possibility that Foley's inside information assisted in the analysis; nor did counsel for the Trust raise this possibility. The Trust relied principally on the argument that disqualification necessarily entails denial of access to work product. Brief for Plaintiff-Appellee at 15, 17, First Wis. Mortgage Trust v. First Wis. Corp., 571 F.2d 390, vacated, 584 F.2d 201 (7th Cir. 1978) (en banc).

127 See note 97 supra. 
tine or nonfactual legal work. The difficult task for a court is to recognize these situations in which denial of access is not required to serve the purposes of disqualification.

1. Work Performed by Persons To Whom the Knowlege of the Firm May Not Realistically Be Attributed. In Edilcentro International, $L t d$. $v$. Porco, ${ }^{128}$ the disqualified firm had formerly been general counsel to a corporation that was joined after discovery as a codefendant in the suit. ${ }^{129}$ The work product in dispute was of two types: legal memoranda written by a summer law clerk and a first year associate, and the work papers of an accounting firm hired by the law firm. In its first work-product order, ${ }^{130}$ the district court rejected "the proposition that disqualification of [the law firm] herein necessarily requires a denial of access to the requested materials," 131 and ordered the work product to be submitted to the court for in camera inspection. In its next order, ${ }^{132}$ issued a year later, the court decided that in camera inspection was improper ${ }^{133}$ and denied access to the entire work product. With respect to the legal memoranda, the court stood by its decision notwithstanding its assumption that "these memoranda were prepared by people who were working in a factual vacuum;" 134 with respect to the accounting work papers, the court denied access because they were based on documents selected by the law firm and on information given to the accountants by the firm. ${ }^{135}$

The Edilcentro order was needlessly harsh. To deny access to the legal memoranda without regard for whether they were prepared in a "factual vacuum" is to suppress the work whether or not it might reveal confidences. The court's suggestion that the legal issues treated in the memoranda were framed by a member of the firm who presumably had access to the confidential information ${ }^{136}$ is unpersuasive; the analysis in the memoranda was routine and in no way created for the special circumstances of the case. ${ }^{137}$

\footnotetext{
128 No. 75-6488 (S.D.N.Y. Dec. 12, 1978) (order denying access to work product).

123 See Edilcentro Int'l Ltd. v. Porco, No. 75-6488, slip op. at 1, 3 (S.D.N.Y. Jul. 30, 1976) (disqualification order).

130 Edilcentro Int'l Ltd. v. Porco, No. 75-6488 (S.D.N.Y. Dec. 30, 1977) (order for in camera inspection of work product).

i3! Id., slip op. at 9.

132 Edilcentro Int'l Ltd. v. Porco, No. 75-6488 (S.D.N.Y. Dec. 12, 1978) (order denying access to work product).

${ }^{133}$ Id., slip op. at 3-5.

is Id. at 6.

13s Id. at 8-9.

136 Id. at 10 n.5.

197 The memoranda concerned case law on brokers' duties and liabilities, the law on imputation of knowledge in agency, and common-law and statutory liability of aiders and
} 
Treating summer clerks and young associates differently from partners or associates who are closely involved with a client has substantial support in the case law of disqualification. Although such junior lawyers are subject to the Code of Professional Responsibility, including disqualification and vicarious disqualification, ${ }^{138}$ courts have often recognized the practical reality of the status of the young lawyer, and have distinguished "lawyers who become heavily involved in the facts of a particular matter [from] those who enter briefly on the periphery for a limited and specific purpose relating solely to legal questions." 139 This distinction cuts with still greater force on the question of access to the junior attorney's work product. Realistically, the junior attorney is not privy to confidential information not necessary to his narrow task; there is, therefore, little reason to suppress his work product unless it was directly based on confidential materials.

2. Work Performed by Persons Isolated from Exposure to Confidences. Within some large law firms-especially multi-city firms-it may be unlikely that the confidences of a client are shared by all the members of the firm representing clients with potentially conflicting interests. Some firms attempt to construct a "Chinese Wall" to insulate certain members of the firm from contact with others. Such an arrangment may not be sufficient protection for a former client so as to make disqualification unnecessary; the danger always exists that the "Wall" will be breached. ${ }^{140}$ With regard to

abettors. Id. at 5. Similarly, the accountant's papers were prepared under general instructions to trace the flow of funds through the defendant corporations in order to locate the sum of money that was the source of the dispute. Id. at 7. None of the lawyers who communicated with the accountants had any connection with the prior representation. A different result might be mandated if there were any evidence that attorneys who had formerly represented the defendant had imparted any information to guide the accountants to particular portions of defendant's records.

${ }_{138}$ Silver Chrysler Plymouth, Inc. v. Chrysler Motor Corp., 518 F.2d 751, 756-57 (2d Cir. 1975); Consolidated 'Theatres, Inc. v. Warner Bros. Circuit Management Corp., 216 F.2d 920, 927 (2d Cir. 1954). See also NCK Organization v. Bregman, 542 F.2d 128, 133 (2d Cir. 1976).

133 Silver Chrysler Plymouth, Inc. v. Chrysler Motor Corp., 518 F.2d 751, 756 (2d Cir. 1975). See also Gas-A-Tron v. Union Oil Co., 534 F.2d 1322, 1323-24 (9th Cir.) (per curiam), cert. denied, 429 U.S. 861 (1976); Laskey Bros., Inc. v. Warner Bros. Pictures, Inc., 224 F.2d 824, 827 (2d Cir. 1955), cert. denied, 350 U.S. 982 (1956); Liebman, supra note 2, at 1002-04.

${ }^{110}$ See, e.g., Westinghouse Elec. Corp. v. Kerr-McGee Corp., 580 F.2d 1311, 1321 (7th Cir.), cert. denied, 99 S. Ct. 353 (1978). See also Cinema 5, Ltd. v. Cinerama, Inc., 528 F.2d 1384, 1387 (2d Cir. 1976). But see Central Milk Producers Coop. v. Sentry Food Stores, Inc., 573 F.2d 988, 991-93 (8th Cir. 1978) (approving an arrangement screening the "tainted" attorney in a Canon 9 case). For a discussion of Chinese Walls and "revolving doors," see Liebman, supra note 2, at $1011 \mathrm{n} .57$ (examining the controversy surrounding the impact of Canon 9's restrictions on former government attorneys returning to private practice in Washington, D.C.). 
work product, however, the court need only determine whether the "Wall" has in fact remained intact, a task that is far less difficult than predicting its future efficacy.

One example of the difficulties of the "Chinese Wall" approach is the recent disqualification of the Chicago law firm of Kirkland \& Ellis in Westinghouse Electric Corp. v. Kerr-McGee Corp. ${ }^{141}$ Kirkland's Washington, D.C., office represented the American Petroleum Institute ("API") in connection with congressional hearings on the oil industry. One of the issues in the hearings was the competitive effect of the ownership by oil companies of uranium production facilities. During the course of the representation, Kirkland's Washington office obtained extensive data from API members under a strict pledge of confidentiality. The Chicago office during this time was preparing a suit on behalf of Westinghouse against 29 uranium producers, including three API members who had supplied the Washington office with data. On the day the Washington office released the API report which described the healthy competitive atmosphere in the uranium industry, Kirkland's Chicago office filed suit on behalf of Westinghouse, alleging that the uranium producers had conspired to restrain trade in violation of the Sherman Act. ${ }^{142}$ Evidence showed that the Washington office was unaware of the Westinghouse suit until it was filed and that the Chicago office knew nothing of the substance of the API representation. ${ }^{143}$ Kirkland claimed that it had constructed a "Chinese Wall" separating the attorneys working on the two matters. ${ }^{144}$

The work-product issue has not yet reached the court in Westinghouse, but substitute counsel has announced its intention to attempt to obtain access to documents prepared by Kirkland's Chicago office. ${ }^{145}$ The court will thus have the opportunity to decide what effect a "Chinese Wall" arrangement should have on the access question. The appellate court did not have to analyze the effect of Kirkland's "Chinese Wall" very closely to decide the disqualification issue; even if there were no threat to confidences under Canon 4 , there was a simultaneous adverse representation, prohibited by Canon 5. ${ }^{146}$ To decide the access question, however, the court must

111580 F.2d 1311 (7th Cir. 1978).

142 Id. at 1312-16. The facts are set out in more detail in the district court's opinion, 448 F. Supp. 1284, 1287-1300 (N.D. Ill. 1978).

14380 F.2d at 1321.

14 Id. Evidence established only one breach of this wall; one Chicago-based attorney involved in the Westinghouse matter agreed to prepare on behalf of API a memorandum analyzing arguments for extending the antitrust laws to prohibit interlocking directorates.

us Nat'l L.J., Nov. 20, 1978, at 3, col. 1.

"' Kirkland argued, and the district court agreed, that there was no breach of Canon 5 
examine Kirkland's procedures closely to see if there was any realistic possibility that the confidences of the API members were used in the Westinghouse matter. The facts of the case suggest there was no such possibility. The physical separation of the two offices decreases the likelihood of casual contact; the one overlap in the representations that did occur had nothing to do with uranium. ${ }^{147}$ Moreover, both the API matter-because of agreement-and the Westinghouse antitrust suit-because of securities laws-were kept confidential even within the firm. ${ }^{148}$ These circumstances bolster the testimony by affidavit of the attorneys in the Westinghouse suit that they did not communicate with the Washington office on the matter and did not have access to the confidential materials. ${ }^{149}$

3. Routine or Nonfactual Legal Work. Some of the most troublesome work-product cases are likely to concern work done by disqualified counsel on purely legal or procedural questions, or in compiling, analyzing, and indexing documents. It may generally be said that such work is unlikely to be tainted; ${ }^{150}$ in some cases, however, seemingly routine or nonfactual work will be highly influenced by the possession of inside information. ${ }^{151}$ A general rule thus will not suffice. The trial court must make its decision based on a close and detailed analysis of the ethical breach and the nature of the work product.

In the First Wisconsin case, for example, the court should have determined what previous contact Foley lawyers had with the loans in question. Apparently, Foley lawyers attended and took minutes of meetings at which the loan agreements were formally discussed

because there was no attomey-client relation between Kirkland and the individual members of API. 448 F. Supp. at 1300-03. The court of appeals rejected this narrow construction of the elements necessary to give rise to the fiduciary relation. 580 F.2d at 1318-20.

167 See note 144 supra.

14848 F. Supp. at 1293, 1296.

148 See id. at 1296.

150 Legal work done on substantive areas not related to the prior representation should almost always be untainted. Similarly innocuous is work performed before the cause for disqualification arose-for example, before the arrival of an attorney whose presence requires the disqualification of the entire firm. See First Wisconsin, 584 F.2d at 216 (Castle, J., dissenting in part, concurring in part).

15t For example, the initial pleadings are usually unobjectionable. In some cases, however, illicit information may have been used to uncover the cause of action. In such cases, the pleadings must be stricken. Doe v. A Corp., 330 F. Supp. 1352 (S.D.N.Y. 1971), aff'd per curiam sub nom. Hall v. A. Corp., 453 F.2d 1375 (2d Cir. 1972); Slater v. Rimar, Inc., 462 Pa. 138, 338 A.2d 584 (1975).

Judge Castle has reasoned that papers filed with the court tend to be less prejudicial than other work product, because the other party has the opportunity to inspect them and to detect any confidential information disclosed. 584 F.2d at 216 n.8 (Castle, J., dissenting in part, concurring in part). 
and approved. In a few instances the firm did substantive analysis of the loans. ${ }^{152}$ With the exception of the latter, the court might be justified in concluding that witnessing the mere formal presentation and approval of the agreements gave Foley no unfair advantage in the subsequent suit. The files pertaining to the loans Foley had previously analyzed could be pulled and the remainder turned over to substitute counsel.

Once the party seeking access has convinced the court that the work done by disqualified counsel was routine and that there is no realistic likelihood that the work reflects confidential information, the burden shifts to the party opposing access. That party should have the opportunity to prove that portions of the work product are tainted, where appropriate by in camera inspection of the work product by the court.

The propriety of in camera proceedings for the purpose of evaluating disqualification motions has been much debated by the courts; ${ }^{153}$ few courts have employed them. ${ }^{154}$ Although the propriety of such proceedings has arisen less frequently in work-product cases, the courts are split. ${ }^{\mathbf{1 5 5}}$ The hesitancy to use in camera inspection of documents is understandable. It is a cumbersome and timeconsuming process for the court; ${ }^{156}$ it is an inadequate protection for the former client, since he should not have to bring potentially embarrassing information to the attention of the court in order to banc).

132422 F. Supp. 493, 498 (E.D. Wis. 1976), rev'd, 584 F.2d 201, 202 (7th Cir. 1978) (en

${ }_{135}$ Compare Government of India v. Cook Indus., Inc., 569 F.2d 737, 741 (2d Cir. 1978) (Mansfield, J., concurring) and Consolidated Theatres, Inc. v. Warner Bros. Circuit Management Corp., 216 F.2d 920, 926 (2d Cir. 1954) with Emle Indus., Inc. v. Patentex, Inc., 478 F.2d 562, 571 (2d Cir. 1973) and Richardson v. Hamilton Int'l Corp., 333 F. Supp. 1049, 1051 (E.D. Pa. 1971), aff'd, 469 F.2d 1382 (3d Cir. 1972), cert. denied, 411 U.S. 986 (1973). In the most recent appellate court decision, in camera proceedings were rejected on the grounds that this "would require the disclosure of the very matters intended to be protected by the rule." Westinghouse Elec. Corp. v. Gulf Oil Corp., 588 F.2d 221, 224 n.3 (7th Cir. 1978) (quoting T.C. Theatre Corp. v. Warner Bros. Pictures, Inc., 113 F. Supp. 265, 269 (S.D.N.Y. 1953)).

15 See, e.g., Fred Weber, Inc. v. Shell Oil Co., 566 F.2d 602, 605 (8th Cir. 1977), cert. denied, 436 U.S. 905 (1978); cf. Garner v. Wolfinbarger, 430 F.2d 1093, 1104 (5th Cir. 1970), cert. denied, 401 U.S. 974 (1971) (in camera inspections in a trade secrets case).

iss Compare First Wis. Mortgage Trust v. First Wis. Corp., 584 F.2d 201, 209 (7th Cir. 1978) (en banc) (endorsing use of in camera proceedings to evaluate motions for access to work product) with Edilcentro Int'l Ltd. v. Porco, No. 75-6488, slip op. at 3 (S.D.N.Y. Dec. 12, 1978) (order denying access, concluding that in camera inspection is inappropriate).

${ }_{156}$ See First Wis. Mortgage Trust v. First Wis. Corp., 584 F.2d at 212 (Castle, J., dissenting in part, concurring in part). In a case such as Westinghouse Elec. Corp. v. Kerr-McGee Corp., 580 F.2d 1311 (7th Cir.), cert. denied, 99 S. Ct. 353 (1978), in which more than one million pages of documents have been put at risk by the disqualification of plaintiff's counsel, such a process seems unduly cumbersome. See Nat'l L.J., Nov. 20, 1978, at 11, col. 1. 
obtain its protection; ${ }^{157}$ and it is an ineffective means of identifying tainted work product. ${ }^{158}$ Nevertheless, in some cases in camera inspection may be useful. Both the burden of the inspection and the undesirable exposure of the court to information embarrassing to the former client may be alleviated by appointing a special master to examine the work product. ${ }^{159}$ The procedure will admittedly remain an ineffective means of spotting tainted work product, but this ineffectiveness is not a great concern, since it will already have been established that there is no reasonable likelihood that the work product reflects confidential information. For the limited purpose of providing the opponent of access one last opportunity to prove that the work product is tainted, in camera inspection seems unobjectionable.

\section{Rebutting the Presumption of Taint: The Timeliness of the Disqualification Motion}

Many reported disqualification cases concern motions for disqualification that were made long after the moving party learned of the grounds for disqualification, ${ }^{180}$ giving rise to some suspicion of the movant's good faith. ${ }^{161}$ Such delay might be explicable upon two grounds: either the ethical infraction initially appeared unimportant or the moving party sought tactical advantage by delay. Delay tends to encourage the challenged attorney to generate work product for his client. Sometimes this encouragement is more direct, as where the party files interrogatories for opposing counsel to answer. The court should not reward such gamesmanship, nor should it give

157 Note, Disqualification of Attorneys for Representing Interests Adverse to Former Clients, 64 Y ALE L.J. 917, 926 (1955).

${ }^{158} 584 \mathrm{~F} .2 \mathrm{~d}$ at 212-13 (Castle, J., dissenting in part, concurring in part). Only when particular secrets are transcribed in the work-product documents will the court be able to identify them. In the more common situation, where the illicit information is used to guide or focus the work product's creation, the court will be unable to detect anything amiss. But see Note, supra note 56, at 1071 ("The court . . . can remove any uncertainty about work product by inspecting in camera the documents sought by substitute counsel.") (footnotes omitted).

150 Cf. Fisher Studio, Inc. v. Loews, Inc., 232 F.2d 199 (2d Cir.), cert. denied, 352 U.S. 836 (1956) (special master appointed to investigate the asserted grounds for disqualification). Costs might be assigned to the party losing on the motion.

${ }^{160}$ E.g., First Wis. Mortgage Trust v. First Wis. Corp., 584 F.2d 201, 203 (7th Cir. 1978) (en banc) (delay during course of adversary negotiations); Koehring Co. v. Manitowac Co., 418 F. Supp. 1133 (E.D. Wis. 1976) (same); Marco v. Dulles, 169 F. Supp. 622, 632 (S.D.N.Y. 1959) (nineteen year delay).

ist Judge Castle suggested that when the timing of the motion for disqualification indicated an intent to harass the other party, such lack of good faith might be given weight in the access decision. 584 F.2d at $216 \mathrm{n} .8$ (Castle, J., dissenting in part, concurring in part). 
more protection to the moving party than is warranted by the party's concern with his own protection.

Although in some cases, delay in moving for disqualification should result in a denial of the disqualification motion itself, ${ }^{162}$ where the interest of the public in maintaining the integrity of the judicial process is paramount, a party's delay should not preclude disqualification. ${ }^{163}$ But denial of access to work product does not substantially promote the public purposes of disqualification. Such denial serves only to protect the former client from the potential use of prejudicial information imparted to a lawyer in confidence. ${ }^{16-1}$ Consequently, there is no public policy bar to permitting parties to waive, by a delayed motion, ${ }^{165}$ their rights to protest access to work product. Sound policy reasons support such a timeliness requirement. Not only would it decrease the opportunity for litigious gamesmanship, and thereby promote the goal of judicial fairness and economy, it would also decrease the wasteful process of the creation of work product that ultimately must be suppressed. A party seeking access should therefore be able to invoke a timeliness requirement as an independent ground for rebutting the presumption that work product is tainted. A party should be deemed to have waived his right to object to the passing on of work product created after he knew or should have known ${ }^{186}$ of the grounds for disqualifi-

102 Central Milk Producers Coop. v. Sentry Food Stores, Inc., 573 F.2d 988, 992 (8th Cir. 1978) (party may not delay disqualification motion "in order to use the motion later as a tool to deprive his opponent of counsel of his choice after substantial preparation of a case has been completed"). See also Lau v. Valu-Bilt Homes, Inc., 582 P.2d 195, 202-03 (Hawaii 1978); Brasseaux v. Girouard, 214 So. 2d 401, 409 (La. App.) (dictum), writ refused, 253 La. 60, 216 So. 2d 307 (1968); Gottwals v. Rencher, 60 Nev. 35, 48, 98 P.2d 481, 487 (1940).

I13 One commentator has observed: "It must be remembered that an attorney is a servant of the state-an officer of the court-as well as a representative of his client. The client cannot waive the rights of the state." Kaplan, Forbidden Retainers, 31 N.Y.U.L. REv. 914, 925 (1956) (footnote omitted). See Emle Indus., Inc. v. Patentex, Inc., 478 F.2d 562, 574 (2d Cir. 1973); Koehring Co. v. Manitowoc Co., 418 F. Supp. 1133, 1138-39 (E.D. Wis. 1976); American Dredging Co. v. City of Philadelphia, 389 A.2d 568, 571 (Pa. 1978); Earl Scheib, Inc. v. Superior Court, 253 Cal. App. 2d 703, 61 Cal. Rptr. 386 (1967); cf. Westinghouse Elec. Corp. v. Gulf Oil Corp., 588 F.2d 221, 228-29 (7th Cir. 1978) (rejecting an argument of waiver in a Canon 4 case on the basis that "it is impossible to conclude that a client could ever have any reason to desire that information disclosed in confidence should be utilized against him"); Empire Linotype School, Inc. v. United States, 143 F. Supp. 627, 631 (S.D.N.Y. 1956) (court can disqualify counsel on its own motion).

su See text and notes at notes 62-66 supra.

tos Nor is there a public policy bar to settlements of disputes over work product, such as that proposed in First Wisconsin. The Trust proposed that First Wisconsin be permitted access on the condition that the Trust receive access to the Foley work product as well. 584 F.2d at 211 n.5 (en banc majority opinion); 571 F.2d at $401 \mathrm{n}^{*}$ (panel opinion, Pell, J., dissenting in part, concurring in part).

is The Code of Professional Responsibility is self-enforcing by design; it requires an 
cation and before his filing of either a motion for disqualification or a formal request to the former attorney to withdraw from the matter. ${ }^{187}$

\section{CoNCLUSION}

The client of a disqualified attorney faces considerable additional litigation costs: delay of his action, loss of the counsel of his choice, and the cost of substituting new counsel. His loss may be greatly magnified if his substitute counsel is denied access to the preparatory work done by the disqualified attorney. The prospect of inflicting so great a loss upon the opponent may tempt the other party to pursue disqualification and denial of access to work product in situations where regard for professional ethics and protection of the client's interests do not strictly demand it. Consequently, courts should take care to exercise their power to suppress the work product of disqualified counsel only where such suppression is required to accomplish the purposes of the disqualification itself.

This comment has suggested a method for deciding when access to work product should be granted to substitute counsel and when it should be denied. When the former client of an attorney obtains the attorney's disqualification in order to protect his confidences or secrets, a presumption arises that the attorney's work product is tainted as well. Substitute counsel may rebut this presumption, by proving either that there was no realistic possibility that the confidences were reflected in the work product, or that the motion for disqualification was untimely. Such an approach would achieve a reasonable accomodation of the valid interests of the former client, the client who faces the burdens imposed by disqualification of counsel, and a judicial system already beset by protracted litigation resulting from tactical delay.

John P. Gyorgy

attorney to decline or withdraw from employment when representation is improper. See, e.g., ABA Code of Professional ResponsibitTY, EC 4-5 (1975). The burden should not be placed on the opposing party to discover his opponent's breach. The requirement that waiver occur when the party "should have known" of the ethical breach is purely evidentiary; any doubts should be resolved against the offending attorney.

107 Since the grounds for disqualification will often be known before a suit is filed, and thus before a motion for disqualification can be made, a formal request to the attorney to withdraw would accomplish the same purpose as a motion. This would avoid a situation such as that in First Wisconsin, in which Foley \& Lardner represented First Wisconsin in adversary negotiations for over a year without objection from the Trust, although the Trust was fully cognizant of the fact that Foley had been its general counsel. 584 F.2d at 202-03. 